\title{
清酒という言葉について
}

\begin{abstract}
本来的な意味での清酒は，清酒に合成酒を包摂した日本酒の概念のな かに埋没せしめられてしまう危険をはらんでいる。さらに消費者保護な いし消費者パワーの抬頭がこれに追い打ちをかけて, 清酒はその原点に もう一度立ち帰って, 酒造の技術, 行政, 経営など全般のあり方につい て洗いなおしてみることが, 緊急事として要請されている。筆者は, べ ストセラーになった「日本人とユダヤ人」を書いたイザヤ・ベンダサン の笔計り（さおばかり）の例を採用しながら，この重要な問題を肩のこ らない読物風に展開している。
\end{abstract}

白潵酒造(株)

高 橋 敬一郎

\section{1. 清酒という言葉は誰のものか}

昨年度のベストセラーの一つとなった「日本人とニダ ヤ人」の著者イザヤ・ベンダサンが，ある月刊雑誌1)に こんなことを書いていました。

『…(前略) …従って私は, 日本といら世界は, 一種の 天科の世界（もしくは竿計りの世界）であると考えてい ます。

そして，これの支点となっているのが「人間」という 概念で，天科（もしくは竿計り）の皿の方にあるのが 「実体語で組立てられた」世界で，分銅になっている方 が「空体語で組立てられた」もら一つの世界です。実体 語とか「空体語」とかいら奇妙な言葉をつからことを拉 ゆるし下さい。これ以外に言いようがないからです。

「実体語」は「空体語」に対比するための言葉ですか らここれは応われわれが言ら言葉と同じだとしておき ましょう（もちろん一応の仮定です）。これに対立する 「空体語」とは, まさに, 天秤が平衡を保つために必要 な分銅の役割をしている言葉と拈考光下さい。

従って, この「空体語」を無意味, 無内容の言葉 (こ れはどの国の言葉にもあります）と誤解されませんよう

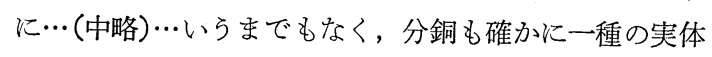
ですが，たとえ質量があり，かつ手でられることができ ても実は一種の尺度であって, 尺度にすぎないといら意 味では実体ではありません。しかし, それでいて, 天科 を水平に保つにはどうしても必要であり, 天科皿の上の 実体と同じだけの重さがなければ，分銅になりません。 問題はここです。…(後略)…』

といら筋で, 以下日本人の言葉と思考の睖昧さを指摘 する文章が続くのですが, この思考方法を, 私達の清酒
という言葉に借用してみましょう。

清酒といら言葉が，いつごろからわが国で使われはじ めたのか私は知りません。だがしかし，しょら油や味噌 などといら言葉と同様に, 濁酒, 白酒と区別されて, 日 本人の庶民の間に古くから用いられてきた言葉にまちが いなさそらです。清酒といら言葉は, 明治政府の法律学 者が発明した言葉でもなければ，清酒製造業者が尃有し ている（あたかも薬メーカーの仁丹や宝丹のごとき）言 葉ではなく，正に日本人庶民の古くから共有する言葉で あると思います。清酒の製造業者は, この清酒といら言 葉によって生業を営み, 大蔵省はこの言葉によって税金 をとっています。あたかもフランスにおけるコニャック やシャンパンに匹敵する実にありがたい言葉であると思 います。

言葉など,どうでもよい。中味さえむともであれば, といら方もいるかも知れません。直接税などたしかにそ らです。納税者が所得税や法人税をごまかすのに，いる んな名目の経費や損金を並べたててみても，内容が異な るならば, 税務署はどんぞん否認して税金を取り立てま す。だがしかし, 間接税, とくに酒税は言葉によって税 金をとっているのです。なぜなら, 酒税法は第一章の総 則で, まず真先に, 酒類の定義と種類を述べ, 言葉の規 定を下しているのがなによりの証拠だと思います。

清酒といら言葉が日本人の庶民のもの（以下消費者の ものと意味を狭めます）だとすると，その消費者の所有 する言葉に, 勝手な解釈を下して税金を取り立てること はゆるされません。そして, 消費者の所有する清酒とい ら言葉は「清酒とは米から醸造した酒だ」という内容を もつことに䛊りはないと思います。これが，イザヤ・心゙ ンダサンのいらところの実体語といたしましょう。する 
々，酒税法に定義しているような「清酒とは」として， イ号清酒（米だけの清酒）と口号清酒（米と同重量の政 令で定めた物品を混入できる清酒）は，それこそ天科計 りの皿にのせる分銅の役目をしているのだから，空体語 となります。そして，日本国民（の代表である国会とい ってもよい）が，この天科計りの支点となりましょう。 天科計りの左の四には, 消費者の使ら清酒といら実体語 がのせられ，右の皿には，酒税法の定義する清酒といら 空体語が，イ号清酒といら刻印の分銅と，口号清酒とい う刻印の分銅といらかたちでのせられている。そらいう 姿を想像して下さい。

さて，われわれが工場で使用する天科計りは毎年検查 をうけ，分銅が正確でなければ取換光させられるか，場 合によっては過料に処せられます。ところが，酒税法の 定義する空体語の清酒といら分銅は，ときどき検査を受 けているかどうか。受ける必要がないかどらか。検査は 誰がするのか。

\section{2. 酒税法は納税者亡徵税者の契約書}

酒税法に限らず, 税法とは国会を通じて納税者と徵税 者との間汇結ばれた契約書とも見做されすす。特に私が この契約書において酒税を取り上げるのは, 清酒の酒税 も, 清酒といら言葉の定義によって税金をとっているか らです。もしも, 清酒といら言葉が大蔵省の専有語であ るならば，その解䊅は自由でありましょう。しかし消費 者のものだとすると, 大蔵省もその解积, つまり空体語 の分銅を勝手には選べない筈です。ところが，戦中戦後， この分銅は随分自由勝手に大蔵省の選択に任せられてき ました。古い話で恐縮ですが，昭和 23 年 10 月 24 日 の日本酒造協会中央会の理事抢よび評議員の合同会議で, 当時の大蔵省平田主税局長は次の上らに述べておられま 寸。

『………本年の産米は, 終戦以来の豊作で是非とも酒 造用の原料米を增やしたいと, 強く関係方面に要望して いる。しかし，毎年この豊作が続くものとは考光られな い。かりに，豊作であったとしても国内的には主食が不 足で, 年々相当大量の食糧を輸入せね齐ばならぬ。…… ちろん，われわれとしても極力米を増やすよう努力する が, 将来に执いても，米を 200 万石（30万トン）といっ たような大量の原料米を獲得することは実現不可能だ。

このため, 今後において, 清酒にいるいろなものを混 合するとか，清酒に合成清酒を混和するとかの結論にな 豆思ら。』(アンダーラインは筆者)

この時, 同じく国税庁大譛間税部長の説明では,

『われわれとして，一応 43 万石（6万 3 千トン）を 割当てて，その上增配分が決ったら追加割当をしたい。
今後食糧米が楽になっても, 私は清酒に使用する米は60 万石（9万トン）とか 100 万石（15万トン）, せいぜい 150 万石 (22 万 5 千トン) 程度であってそれ以上は望め ないと思う。かりに150万石になるとしても果して何年 後にその域に達するか。それはずっと先のことであろ 万。………』

平田局長の『(清酒とは) 清酒にいろいろなるのを混 合するとか, 清酒に合成清酒を混和するとかの結論にな る。』いらことは，清酒といら言葉が，すでに消費者 のものではなく, 大蔵省の専有語になっていることを示 しています。また大㭷部長の言葉は，当時の国民（国 会）の感触を正しく代弁したものといえましょう。

つまり, 天科計りでい党ば，空体語（大蔵省）と支点 （国民）が一致した状態，支点の上に分銅がのせられ， 天秤計りの作用をしていない状態といってょいでしょう。 原料米 200 万石 (30 万トン) はいつの日か, と嘆か れた日本は, それから 10 年後には早くもこのラインに 達し， 46 年度は 370 万石（56万トン）となりました。 200 万石が一つの拤とすれば, 実体語の清酒と空体語の 清酒とが正常な秤にかけられてからも10 年以上も過ぎ ているのです。

こうなると左の四の実体語を所有する清酒の消費者の みでなく支点となっている国民（国会）の側から，分銅 の検查をしようではないかといら声があがるのもやむを えないことだと思います。

日本人には契約書をつくるどころか, 読むことすら臆 劫がる気風があります。生命・火災等の保険証書の裏に びっしりと書いてある契約文句はもちろん, 自分が借り 入れする銀行の約定書でも読まずに印を捺す方が多いの ですから, 酒税法の総則や施行令を読んで, これは契約 違反である，などと騒ぎ立てる消費者が，これまでに無 かったのは幸いなことでした。

同一言語，同一民族でつながる日本人は「まさかあの 人間が」といら感覚が先に立ち, 契約の内容よりも, そ の相手の人間を見抜くカンが重んぜられていますから， 消費者は, 清酒のアルコール分の $45 \%$ が, 芋や糖蜜で つくられている合成酒との合の子清酒など, まさか大藏 省が造らせる筈がないと思っているのでしょう。

\section{3. 経済倫理の進歩と清酒という言葉}

ロースト大和煮といらかん詰がありました。野原に草 を喰む牛を美しく印刷したラベルに似ず，中味が鯨肉だ ったので, 東京都衛生局と都経済局でかん詰業界の幹部 を呼んで事情を聞くとともに，実態調査を行なってみた ら, 肉類か九詰メーカーは全国大手 20 余社あり,この らち、100\% 牛肉を使ったかん詰を造っているメーカー 
は, 東京に 1 社, 大阪に 1 社あるだけ。あとのメーカー の牛かんの中身は 8,9 割まで輸入馬肉でありました。 これが有名な昭和 35 年の「にせ牛かん事件」で, これ が契機となり，農林省は当時の農林物資規格法および同 施行令を，厚生省は食品衛生法および同施行令を，大あ わてで, 改正強化しています。

これは，実は水山の一角だったので，これら品質不当 表示の事件を参考文献2)から拾ってみますと，

『商品または役務の品質, 規格その他の内容について, “実際のもの”より著しく優良であると一般消費者に䛊 認される表示』をしているものの例として，(1)「栗羊か ん」と表示して実際に栗が入っていない。(2)「くるみせ んべい」と表示して,くるみが入っていない。(3)「鯛の 子塩辛」と表示していたが, 実際にはサバの卵であった。 (4)「山ごぼうの味䁚漬」と表示しながら畑ごぼうであっ た。(5)「深山ぶどう」と表示していたが外国産の畭ぶど らであった。(6)牛乳の脂肪にヤシ油等の異種脂肪を混入 したものに純良バターと表示した。(7)牛乳成分が $3 \sim 4$ 割しか入っていない乳飲料に「コーヒー牛乳」「フルー ッ牛乳」等の名称を表示した。(8)チーズに大豆蛋白質を 混入して「プロセスチーズ」と表示。99なみつに水あ めまたは人工転化糖を混入した物に「天然はちみつ」ま たは「ピュア・ハネー」等と表示した。(10水サク酸を使 用して製造した食眽に「酽造酢」と表示。(11粉わさびの 商品名を「わさび」とした上，水わさびと紛らわしい絵 や図案を表示した。(12)実際に卵を使用していないのに 「たまご納豆」といら商品名を付したら光ににわりりの 卵の絵を表した。

こんな例は枚挙にいとまがありません。バターとマー ガリン事件, 生レモンと合成レモン, ジュースの呼称, アイスクリーム，さてはしょう油にまで拡がってきまし た。

「酒は違う，大蔵省の管轄下にあるのたかからとおっ しゃる方が多ければ多いほぼ，この拙文は役に立つこと と内心私は喜んでいるのです。それは「にせかん詰」事 件を契機として, 独占禁止法の第 2 条 7 項 3 号 “不当に 競争者の顧客を自己と取引するよう誘引し，または強制 すること”では, かかる事件を処理できないことが明ら かになりましたので, 昭和 36 年頃公正取引委員会は, 独占禁止法の特別法を制定することに方針を固めたので す。はじめ屾不当表示を排除する立案だったのですが, 折からの経済成長によって激化しはじめた不当景品類の 規制の必要も認められ, 昭和 37 年に「不当景品及び不 当表示防止法」が制定されました。この一連の流れが昭 和 43 年以「消費者保護基本法」に続き, 消費者保護行 政の基礎が固めら机ました。
このことは国際的な消費保護行政の御手本があるから です。アメリカ, イギリス, フランス，西ドイッ等の消 費者保護行政の先進国では, 商品表示の問題は不公正競

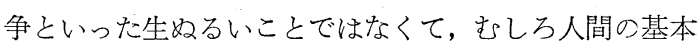
的人権擁護という発想から，その違反は刑法上の詐欺罪 に結びっく法概念によって発達してきたのです。

羊頭狗肉的な商法はなくなりつつあっても，専門家を 除いて「だれにもわからないから」という前近代的な感 覚の残っている官僚国家の国も漸く消費市民パワーの自 覚に警いて国内法の整備に取りかかったわけです。

1962 年, 故ケネディ大統領の消費者保護に関する特 別教書の中で, 消費者の基本的権利として，(1)知らされ る権利 (2)安全の権利 (3)選択の権利 (4)意見を述べる 権利をあげていますが，これぞ正しく近代消費市民社会 の指向すべき目標を述べているものと思います。昭和 44 年の $\mathrm{OECD}$ 加盟国間で開かれた「OECD 消費者政策予備 会議」は, 国際間に益々自由化して流通する食品商品の 表示について, 基本的な統一見解を求めていますが, さ らに FAO (食糧農業機構) と WHO (世界保健機構) は, その合同食品委員会で, 食品の標示 (Label), 表示 (Labelling), 原料 (ingredient) 等について, 用語の定義 づけを行なら「食品標示の一般基準案」がつくられつつ あります。これらは, 輸出入の取引の際にだけその基準 が適用されて, 国内取引は別といら差別が許されるかど らか疑問です。

国内清酒の取引には, サリチル酸を入れてもよいが， 米国に輸出する場合は入れてはならないなどと, 吞気湾 構えていましたら WHO から政府へ勧告がきて国会で点 火されると「大蔵省がついている」では何の役にも立ち ませんでした。

これを例にして，清酒に添加する「アルコール」や 「ぶどら」糖にもと, いらつもりはないのであって, 私 のいいたいのは, こういらことなのです。昔は（あるい は今も）食品は安価, 良質, 安全であればよかった。そ の製造技術は，唯々この方向に努力すればよかった。そ して坂口先生の御言葉を借りればア “清酒の組成の微量 成分に至るまで研究しつくして，それを調合して造る合 成清酒（新清酒）といら他国に例のない酒が完成され” るに到りました。“実際のもの”と“近似したもの”とを 消費者に䛊認させる方向へわが国の技術恃著しい進歩を 遂げて来ました。さらに, 近代の宣伝広告業の素晴しい 発達は, これに拍車をかけたので, 消費者にとって, 何 を代用食料として食べさせられ，何を代用飲料として飲 ませられているか判らない社会がつくり出されてきたと いうことになります。

こらなると, かえって逆に，消費者の方では，らまい, 
まずいは別として，自分の食べから飲むものが，何を原 料とし，どういら製法をとるのかを“知る権利”があり， 造るものは，“知らせる義務”がある，と主張しはじめ てきなした。マーガリンや植物油やしょら油の表示の問 題は，正に消費者の実体語と製造業者の空体語とのアン バランスから起って来たのであります。だから，孜々と して代替品を研究してきた技術者の方々が分析をして, 自然酽造の「アルコール」や「ぶどう糖」や「アミノ酸」 と, 添加したそれらと、どこに，どれだけ違いがあるの か。馬鹿々々しい，と力んでみても消費者の言葉すなわ ち実体語には通用し亡せん。なぜなら消費者保護基本法 が求めているのは,「それはどうでもよい, 製造の原料 やそのプロセスを消費者に知らせることを望み，知らせ る義務がある。その上で，消費者の選択任せなさい。」 といっているのです。

清酒といら言葉が消費者の所有する言葉なら, そして, 契約書に䁓昧な点があるならば，それを正しく表示せよ， といらのが, 清酒についての経済倫理のすう勢でありま す。公害防止と消費者保護といら新しい市民精神の抬頭 は，いらなれば，自然を無視して突走しる技術と広告宣 伝に対する自然のチェックであると思います。

\section{4. 酒税法の欠落部分について}

さてここまでくると, 現行の酒税法や酒団法, そして その政令等には，消費者保護の基本的観念に欠けている 部分があるような気がいたします。

本誌第 66 卷第 9 号比いて, 辻弥兵衛氏が「清酒中 慗メーカーの扮かれた地位とその経営ビジョン」といら 論説の中で「………われわれは，望ましい業界構造とい う問題を考光る場合，何よりも“消費者のために”といら原点を考学るべきであろう。（中略）………酒類 行政は黒沢一清氏の説くごとく国民の健康を守ることを 第一義としなけ机ばならない時代に入りつつあるのであ ろらか。いずれにせよ，日本に抢ける酒類行政は，“消 費者のために”といら発想はほとんどなかったといって よいのではないか?」と問題を提起されておられます。 私もそうだと思います。そして“消費者のために”とい う部分を, 清酒といら言葉（ロゴス）の面からとら光, それを実体語といら表現を用いて，いまわれわれが置か れている環境を見回わしてきました。“消費者のために” といら言葉の内容としては, 黒沢氏のごとく国民の健康 を守ることも必要であり，安くもなけ机ばならないし， らまくひなければなりません。

清酒といら言葉（ロゴス）の面からとらえないで，た とえば，“らまさ”といら言葉で清酒をとらえてみましょ う。
昭和 46 年 8 月 2 日付の $\mathrm{A}$ 新䦕の「暮しのレーダー」 闌に『グルタミン酸ナトリウムに $10 \%$ のイノシン酸を 加光ると，ら专味は 5 倍にアップする。イノシン酸の代 りにグアニル酸といら化学物質を使えば，らま味は 19 倍になる………』とい文章がのっていました。いった い, らま昧を 5 倍，19 倍というように，どうして計量 するのか私は知りません。計量できるといたしましょ う。一方，NHKのあるときのテレビ番組で，パンがよ いかごはんがよいか，2つのグループの討論学みたこ とがあります。結局どちらがうまいかといらことになっ たとき，ごはん党の交響楽団指揮者の岩城宏之氏が、「ご はんはたた啮みしめた口中の味だけでなく、それが咽頭 を通過するときの物理的な味といらか，くすぐりがなん ともいえない」と答えていました。同じ米でも，嗆のら まさ，打茶漬のうまさ，扔かゆのらまさ，これらはさき の 5 倍, 19 倍にアップする “らまさ”とはどうも違うよ らです。パンだって焼き方によって，いろいろな味にな ります。すると，米だけの酒がうまくて，アル添酒がま ずいとはいえません。さきに述べたロースト大和煮の倞 肉だって，下手な牛肉のかん詰よりらまいのかも知れま せん。まさ蓼食ら虫です。ですから，らまいとかまず いとかは言葉ではあっても感覚, 感情 (パトス) の問題 なのです。

酒税法の施行令で,「品質優良なるものを特級とし, 佳 良なるものを 1 級とし，そうでないものを 2 級とする」 といっていますが，ここの優良，佳良もパトスの世界の 用語だと思います。優良とか佳良とかは, 消費者側の用 語です。税金をとる側は空体語，すなわち実体語を計る 分銅となるべき言葉を法令用語として用意しなければな りません。これでは, 蜜柑を計るのに分銅の代りに蜜柑 をのせているに過ぎあせん。

だから，ウィスキー類では，特級，1級をきめるのに 施行令に就いて，優良とか佳良とかといら用語は使って おりません。簡単にい党ば，モルトウイスキー $23 \%$ 以 上入れていないものは特級としない。モルト $13 \%$ 以上 入れていないものは1級としない。という物理的空体語 の分銅を使っています。法令的表現としてはここれが正 しいと思います。

消費者保護基本法の関連法として, 薬事法, 食品衛生 法, 農林物資の規格打よび品質表示の適正化汇関する法 律（農林物資規格法が変ったもの）拉よび家庭用品品質 表示法等は，消費者保護基本法の指向するところに沿う て, 法令が整備強化されつつあるのに, 酒だけは法も政 令もこれに背を向けて, 今のままの酒税法や酒団法でこ と足れりとしてよいでしょうか。この欠落部分は早晚と の補垻を強いられる日が近いものと考光られます。 


\section{5. 清酒製造業者の存在価值について}

以上の久落部分を誰がぞう補うのでしょらか。他人事 ではないのですから，その主役は清酒製造業者でなけれ ばなりません。しかもそれは業者の合意に懸っているの です。その中枢は日本酒造組合中央会にあります。中央 会はいま賏命になって，清酒の宣伝をしています。しか し, 坂口先生の御言葉ど抒り ${ }^{3)}$ 「清酒と合成酒の合の子」 をつくっているのだから日本酒といらのが正しい呼称だ と思います。だから日本一酒造組合中央会と読まないで, 日本酒一造組合中央会の方が今では正しい読み方だと思 います。「清酒はなぜまずい」と書かないで，「日本酒は なぜまずい」と編集者が標題をつけたところにわれわれ

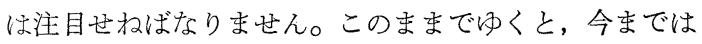
日本酒＝清酒と消費者は考えていますが，そのらちに， 日本酒二清酒十合成清酒といら意味に日本酒といら言葉 が消費者に定着しないとも限りますん。

私共が父祖から受継いだ文化的遺産は, 米からの並行 複発酵といら技術知識（ノウハウ）と，これを象徵する
ところの清酒といら言葉であります。そして，それが私 共が社会に存在する価值の支えとなっているのです。

そのノウハウの $40 \%$ も $50 \%$ も他産業から簡単汇買っ て来て, 量だけ多くして売るならば, その存在価值もそ れだけ低下するに止らず，清酒十合成清酒＝日本酒とい ら言葉に清酒といら言葉は包拱されてしまいましょう。 日本酒造組合中央会は, 名実ともに日本清酒組合中央会 に改まらない限り，その存在価值は低下するばかりか， 清酒製造業者は必要がなくなり，あとに残るのは大手の 日本酒製造業者ばかりとなりましょう。

後記：本稿を草するにあたり, 前日本酒造組合中央会 酒造対策調查委員, 吉田一郎氏の論説扔よび蒐集 された資料に負うところ多大で，記して感謝の意 を表します。

\section{参考 文 献}

1) 赫誌「諸君」昭和 46 年 6 月号(株)文芸春秋

2)「景品表示法」の実狢：吉田文剖編 ダイヤモンド社

3)「日本酒はなぜをずかか」昭和47年新年号 文芸春秋坂口讙一郎 